\title{
Swelling Curve in Terms of Effective Stress for Expansive Clays
}

\author{
Rafael Baltodano-Goulding ${ }^{1,2, *}$ \\ ${ }^{1}$ LabUnsat, Civil Engineering Department, University of Costa Rica, Costa Rica \\ ${ }^{2}$ Construction Engineering, Costa Rica Institute of Technology, Costa Rica
}

\begin{abstract}
Expansive soils can present an unsaturated state where the soil exhibits volume changes due to both moisture variations that change the state of stresses and moisture variations that interact with its mineralogical characteristics. These special kinds of soils are normally clay type soils that had suffered isomorphous substitution creating a charge imbalance of the clay mineral crystals. This imbalance promotes the trapping of water molecules by the clay particles. It is commonly assumed that a high plasticity index can be an indication of a clay's high swell potential. However, in arid regions, it is possible to have clays with very high swell potential and low plasticity indexes due primarily to a decrease in the state of effective stress, which will produce expansion of the material. It is common practice to study the swelling characteristics of these soils by performing free-swell tests that can be used for designing removal and replacement backfills or drilled shafts. However, the expansion percentage obtained from this type of test is actually in terms of total stresses and not in terms of effective stress, as it is commonly assumed. Moreover, it is highly dependent on the magnitude of the preload used. This paper presents some efforts made to obtain the swelling part of the curve in terms of effective stresses from the traditional free-swell test. It was hypothesized that the shape of this curve could either have the shape of the rebound curve from a saturated consolidation test or a shape similar to the soil-water characteristic curve.
\end{abstract}

\section{Introduction}

Expansive soils around the world are responsible for several million dollars in losses, affecting especially light structures such as houses and pavements. The subject of expansive clays has been widely studied at both the microscopic and the macroscopic levels. However, efforts to improve our understanding and design of mitigation measures are still necessary [1].

The volume changes (swelling and contraction) that occur in expansive soils are directly related to the water content variations in the soil that are a function of material and climate-related variables. The material variables are the permeability of the soil, soil structure, and water retention properties. The climate-related variables are captured in the water budget, as the difference in infiltration and evapotranspiration determines the wetting front and fluctuations in the water table. Therefore, the depth of water content variations, where the volume changes occur, must be determined, and in expansive soils theory, this depth defines what is known as the active zone. Thus, the depth of the active zone is the depth of swelling soil within the moisture variation where the soil can heave due to environmental variables. The thickness considered for swelling estimations is not necessarily the total thickness of soils with expansive characteristics, but the thickness of the expansive soil used for swelling estimations is equal to the active zone depth, i.e., the lowest seasonal depth of moisture changes for a particular location.
The expansive potential of clayey soils can be attributed to two main factors: mineralogy or initial low moisture (high matric suction). These special kinds of soils are normally clay type soils that had suffered isomorphous substitution creating a charge imbalance of the clay mineral crystals. This imbalance promotes the trapping of water molecules by the clay particles [2]. It is commonly assumed that a high plasticity index can be an indication of a clay's high swell potential. However, in arid regions, it is possible to have clays with very high swell potential and low plasticity indexes due primarily to a decrease in the state of effective stress, which will produce expansion of the material.

It is common practice to study the expansive characteristics of these soils by performing either a constant volume test or a free-swell test. Both of these tests can be used to determine the swelling percentage of the soil and its swelling pressure, those values can be used to design removal and replacement backfills or drilled shafts. The free-swell test is widely used probably because it is easier to perform; however, the expansion percentage obtained from this type of test is actually in terms of total stresses and not in terms of effective stress, as it is commonly assumed since the soil specimen are not saturated at the start of the test and the state of effective stress is the combination of the preload and the stresses due to the matric suction in the material. Because the matric suction is not measured or even taken into consideration in the effective stress determination and only the external load is, the values commonly 
assumed as effective stresses in the abscissa axis of Figure 1 are actually total stresses. This expansion percentage is highly dependent on the magnitude of the preload used in the test. Thus, it is possible to conclude that the current methodology is in terms of total stresses and not effective stress as it is commonly assumed.

\section{Materials and methods}

\subsection{Materials}

Three undisturbed clayey soil samples were obtained from three different locations in the Central Valley of Costa Rica. Sample 1 and sample 3 were collected during the rainy season, and sample 2 during the dry season. Table 1 shows the results obtained from the soil's characterization.

Table 1. Soil sample characterization. [3]

\begin{tabular}{|c|c|c|c|}
\hline $\begin{array}{c}\text { Index } \\
\text { property }\end{array}$ & $\begin{array}{c}\text { Soil sample } \\
\mathbf{1}\end{array}$ & $\begin{array}{c}\text { Soil sample } \\
\mathbf{2}\end{array}$ & $\begin{array}{c}\text { Soil sample } \\
\mathbf{3}\end{array}$ \\
\hline Liquid limit & 89 & 68 & 120 \\
\hline $\begin{array}{c}\text { Plasticity } \\
\text { Index }\end{array}$ & 55 & 50 & 95 \\
\hline $\begin{array}{c}\text { Plasticity } \\
\text { Chart }\end{array}$ & $\mathrm{CH}$ & $\mathrm{CH}$ & $\mathrm{CH}$ \\
\hline $\begin{array}{c}\text { Specific } \\
\text { Gravity }\end{array}$ & 2.51 & 2.65 & 2.42 \\
\hline $\begin{array}{c}\text { Natural } \\
\text { water } \\
\text { content }\end{array}$ & $40.3 \%$ & $5.1 \%$ & $32.1 \%$ \\
\hline $\begin{array}{c}\text { Degree of } \\
\text { Saturation }\end{array}$ & $99 \%$ & $27.7 \%$ & $100 \%$ \\
\hline $\begin{array}{c}\text { Total Unit } \\
\text { Weight } \\
\text { (kN/m }{ }^{3} \text { ) }\end{array}$ & 17.1 & 18.4 & 18.1 \\
\hline $\begin{array}{c}\text { Void ratio } \\
\text { Porosity }\end{array}$ & 1.02 & 0.49 & 0.78 \\
\hline \begin{tabular}{c} 
Poiti \\
\hline
\end{tabular} & $51 \%$ & $33 \%$ & $44 \%$ \\
\hline
\end{tabular}

The values of the Atterberg limits can provide an approximation to the type of clay minerals present in the soil. Table 2 shows the likely clay minerals for each sample studied.

\subsection{Methods}

The swelling percentage in the laboratory is commonly achieved by performing either a constant volume test or a free-swell test. The free-swell test procedure can be found in ASTM-D4536 method C. Figure 1 shows the typical graphical of the results for this test.
Table 2. Clay mineralogy likelihood for the soils studied. [2][4]

\begin{tabular}{|c|c|c|}
\hline Sample & $\begin{array}{c}\text { Mitchell \& } \\
\text { Soga }\end{array}$ & $\begin{array}{c}\text { Holtz \& } \\
\text { Kovacs }\end{array}$ \\
\hline 1 & $\begin{array}{c}\text { Illite, } \\
\text { Kaolinite }\end{array}$ & Illite \\
\hline 2 & Nontronite & Smectite \\
\hline 3 & Illite & Illite \\
\hline
\end{tabular}

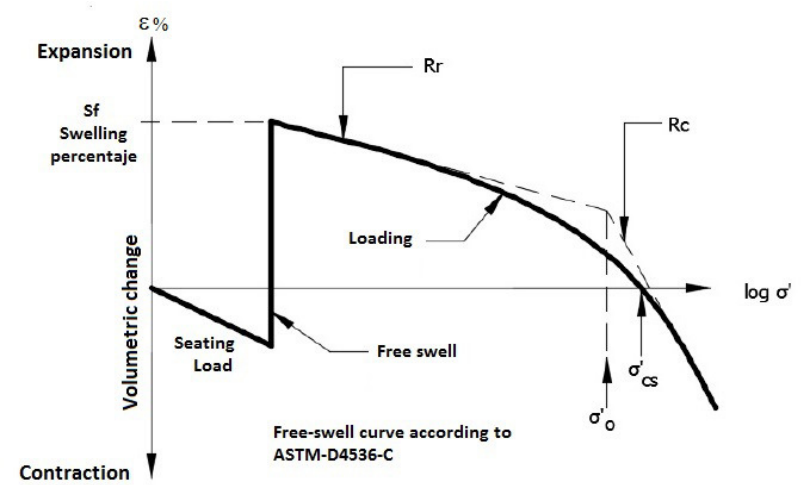

Fig. 1. Graphical result of a typical free-swell test.

The procedure for this test includes an initial stage where a seating load is applied and its corresponding compression is recorded. After this stage is completed the soil sample is inundated and enough time is allowed for the soil to completely stop swelling. The difference from the initial void ratio to the final one after the swelling stopped is used to calculate the swelling percentage. Finally, a compression stage is performed in a similar manner that a typical consolidation test.

From the free-swell test is possible to obtain the recompression ratio $(\mathrm{Rc})$, compression ratio $(\mathrm{Rc})$, maximum past pressure $\left(\sigma^{\prime} \mathrm{o}\right)$, swelling pressure $\left(\sigma^{\prime} \mathrm{cs}\right)$, and the swelling percentage (Sf) for a particular seating load. However, one main disadvantage of the test is that when a swelling percentage at a different pressure than the seating load needs to be estimated, there is no measured curve for the swelling stage, so this percentage is estimated using the compression curve.

The vertical line that represents the swelling stage of the test is measured in terms of total stresses and not in terms of effective stresses, as it is commonly assumed. It is not possible to have a volume change without exhibiting a change in the state of effective stress. Since the volume change is real and measured, this must mean that the effective stress is actually changing; therefore, the initial and the final void ratios cannot be at the same effective stress to produce a vertical line in the graph.

In order to plot the swelling curve in terms of effective stress is necessary to measure or at least estimate the actual effective stress that is a combination of the total stress and the suction stress $(\chi(u a-u w))$. 
Hence, it is imperative that the matric suction of the soil specimen be assessed. Once the matric suction values are known, it is possible to use equation 1 to estimate the effective stress.

$\sigma^{\prime}=\sigma_{t}-u_{a}+\chi\left(u_{a}-u_{w}\right)$

Two techniques were used to measure the matric suction of the soil specimens: paper filter and a tensiometer. Figures 2, 3, and 4 show the Soil-water characteristic curve for all three specimens determined using the measured data and the van Genuchten model with the aid of the RECT computer program of the Environmental Protection Agency of the United States of America [5]. It is worth mentioning that the matric suction was determined twice: first, a tensiometer was placed into the free-swell test specimen and left in place for the remaining of the test, and the second, on an identical specimen prepared and used to measure suction with both a tensiometer and with the paper filter technique. The reason for the second approach was to minimize disturbance of the swelling measurement that arise from having the tensiometer inside the soil specimen. To assure the representativeness of the suction values taken from the indirect method, the specimens were constructed in the same oedometer apparatus and following the same procedure as the free-swell test, using Ladd's undercompaction method [6] to control the density, thus producing similar soil specimens.

The estimation of the effective stress parameter $\chi$ can be done by different methodologies such as Bishop (equals to the degree of saturation), Khalili \& Khabbaz (based on a suction ratio related to the air entry pressure), Vanapalli \& Fredlund (equals the degree of saturation to the power of a statistically fitting parameter), and van Genuchten (equals to the effective saturation, i.e. a normalized water content) [6]. For this research, the effective stress parameter was calculated as equal to the degree of saturation.

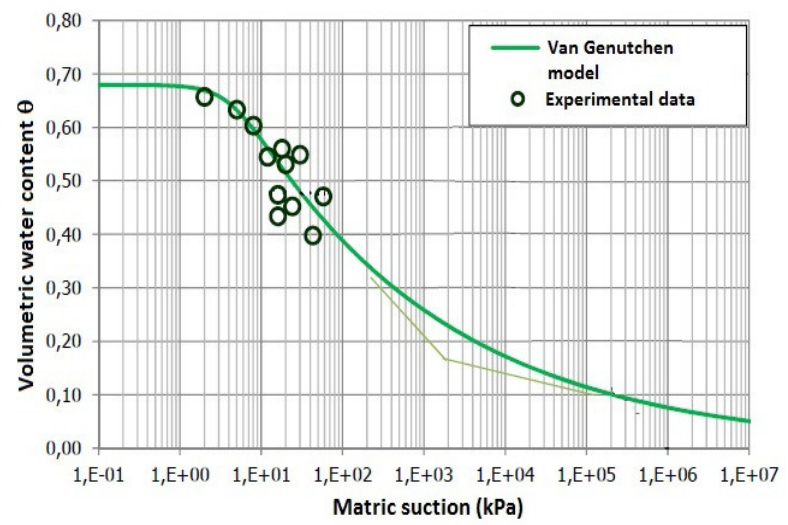

Fig. 2. Soil-water characteristic curve for soil 1. [3]

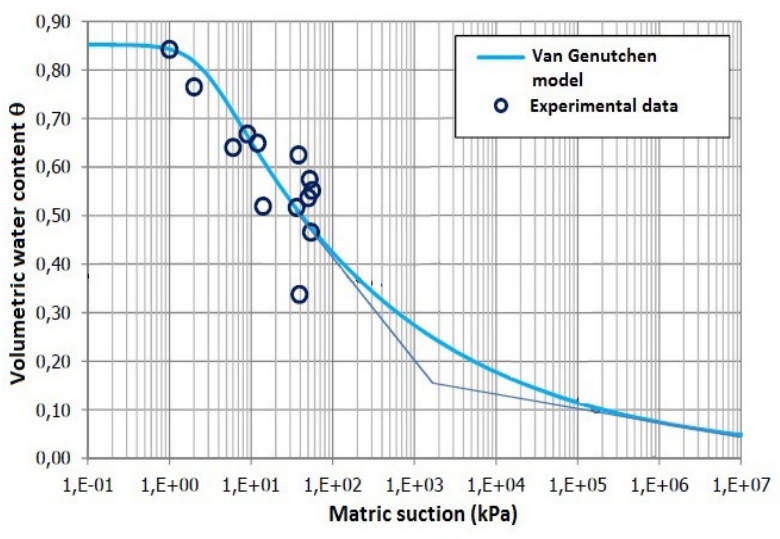

Fig. 3. Soil-water characteristic curve for soil 2. [3]

Once the Soil-water characteristic curve for all three specimens was determined, it was necessary to measure the water content changes as the soil heaved so the matric suction could be calculated as a function of time. Having the matric suction varying with time allows estimating the effective stresses using equation 1 . Once the effective stresses are estimated the swelling curve can be assessed and used to calculate the swelling percentages for different surcharges, which is necessary to select the appropriate depth of soil replacement.

In order to measure the water content changes, it was necessary to make some modifications to the test procedure shown in Figure 5. It is common that as the soil swells, and absorbs water, the level of water in the consolidation cell decreases. Normally, the person in charge of running the test is required to assure that the water level does not drop enough to allow air to enter the specimen. But for this research, because it is imperative that the volume of water entering the soil be known to calculate the water content changes, close control was taken of the volume of water added in order to maintain the water level in the cell at a constant level. The added volume of water is assumed to be equal to the water absorbed by the soil specimen plus the water that has been evaporated. If a similar calibrated container is placed beside the consolidation cell the evaporation can be estimated.

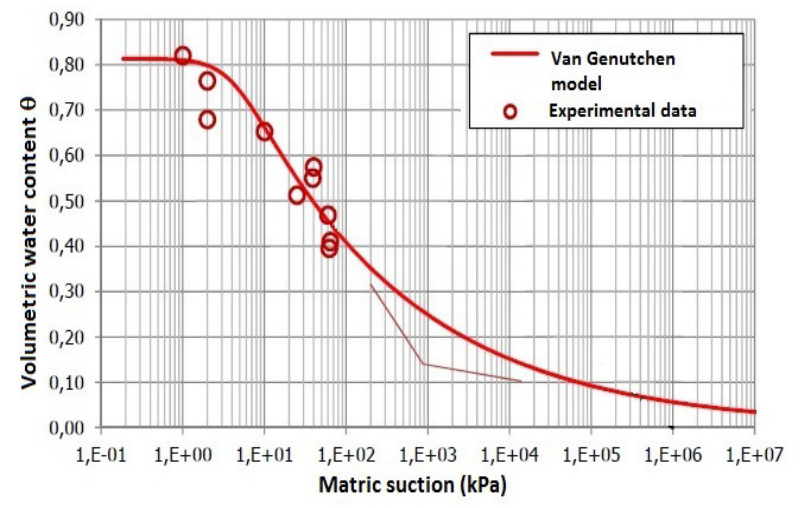

Fig. 4. Soil-water characteristic curve for soil 3. [3] 


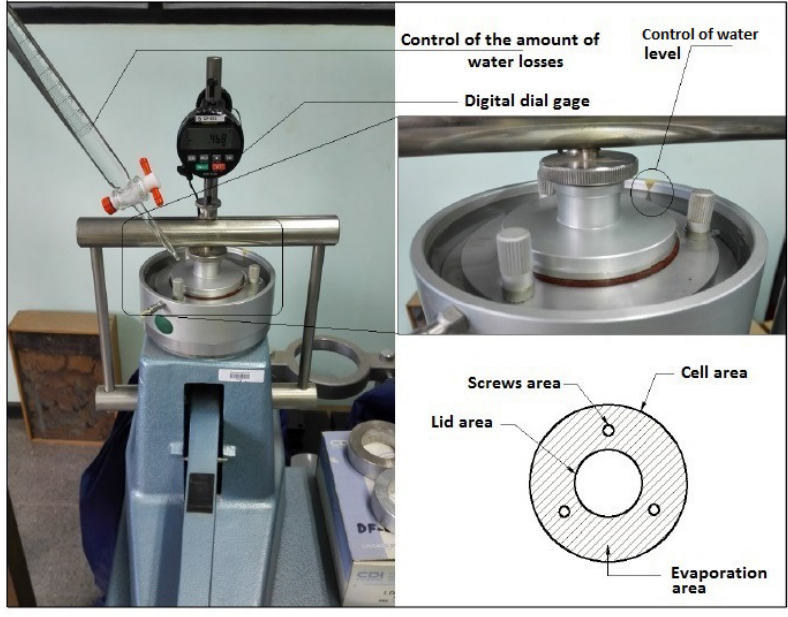

Fig. 5. Modifications to the free-swell test procedure. [3]

\section{Results and Analysis}

\subsection{Results}

It was hypothesized that the actual swelling curve in terms of effective stresses could have three possible shapes. Figure 6 illustrated the alternatives for these shapes.

Alternative 1 could be a possibility if the rebound curve of a typical consolidation test is taken as a probable swelling path when the state of stresses is reduced due to a reduction in the surcharge. Alternative 2 could be a possibility if is taken into consideration that in the actual test in the lab a greater amount of expansion is normally observed at the beginning of the test. And, alternative 3 reasoning arises from the assumption that because the expansive soil, at a drier stage, is in an unsaturated state, it could follow a path similar to the Soil-water characteristic curve for that particular soil.

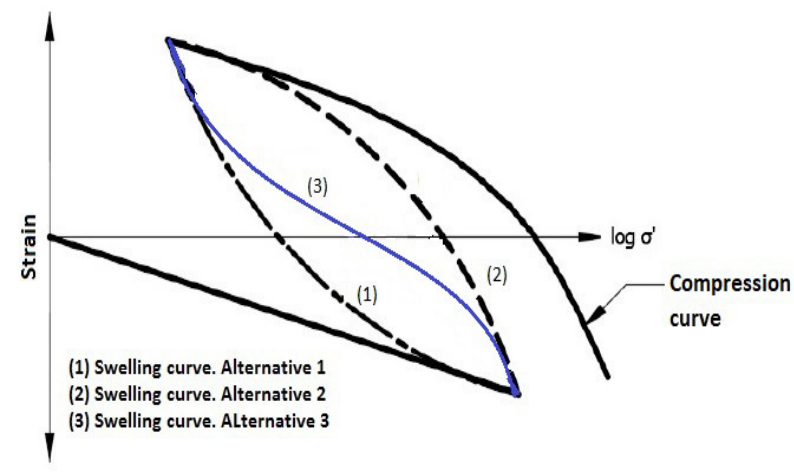

Fig. 6. Hypothesized swelling curves shapes.

After using an LDVT to constantly record the axial strain it was determined that the shape of the actual swelling curve is similar to alternative 3 . Figure 7 shows the matric suction values as a function of gravimetric water content for the three specimens performed.

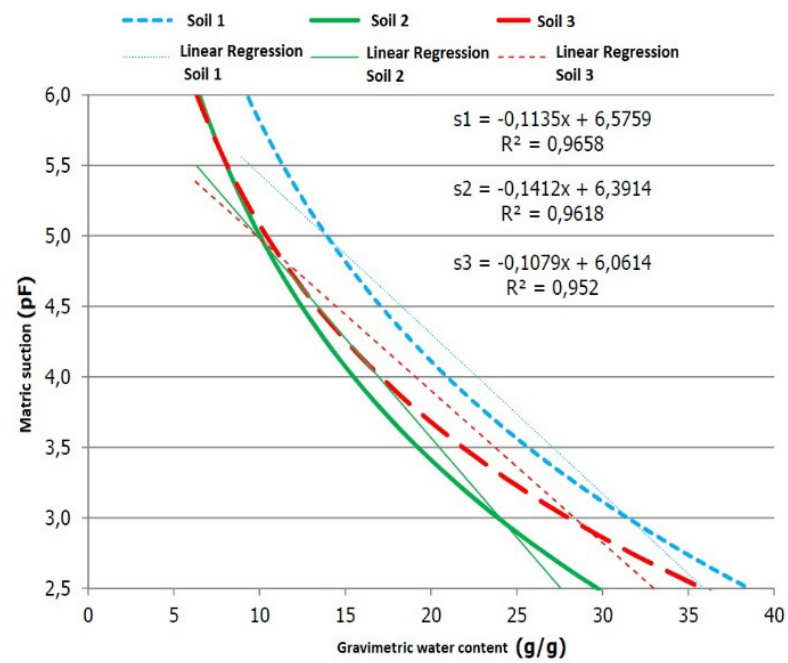

Fig. 7. Soil-water retention curve using the RECT computer program of the Environmental Protection Agency of the United States of America.[5]

The initial effective stress considering the matric suction and the final effective stress considering matric suction at the end of the swelling process are shown in table 3. This table also includes the measured swelling percentage. It is worth mentioning that these suction values were estimated utilizing Figure 7.

\subsection{Analysis}

In order to assess the effect that this proposed swelling curve might have in geotechnical engineering practice, a comparison between the depths of soil substitution calculated for a shallow foundation using both approaches (considering the effective stress in a conventional way, and considering the matric suction contribution to the effective stress) were evaluated. Figure 8 and Table 4 show the variables used in the calculations.

Table 3. Effective stress considering suction at the beginning and end of the swelling process and its corresponding swelling percentage. [3]

\begin{tabular}{|c|c|c|c|}
\hline Soil & $\begin{array}{c}\text { Initial } \\
\text { Effective } \\
\text { stress } \\
\text { considering } \\
\text { matric } \\
\text { suction }\end{array}$ & $\begin{array}{c}\text { Final } \\
\text { Effective } \\
\text { stress } \\
\text { considering } \\
\text { matric } \\
\text { suction }\end{array}$ & $\begin{array}{c}\text { Swelling } \\
\text { percentage }\end{array}$ \\
\hline 1 & $37 \mathrm{kPa}$ & $30 \mathrm{kPa}$ & 2 \\
\hline 2 & $240 \mathrm{kPa}$ & $200 \mathrm{kPa}$ & 11 \\
\hline 3 & $200 \mathrm{kPa}$ & $165 \mathrm{kPa}$ & 8 \\
\hline
\end{tabular}




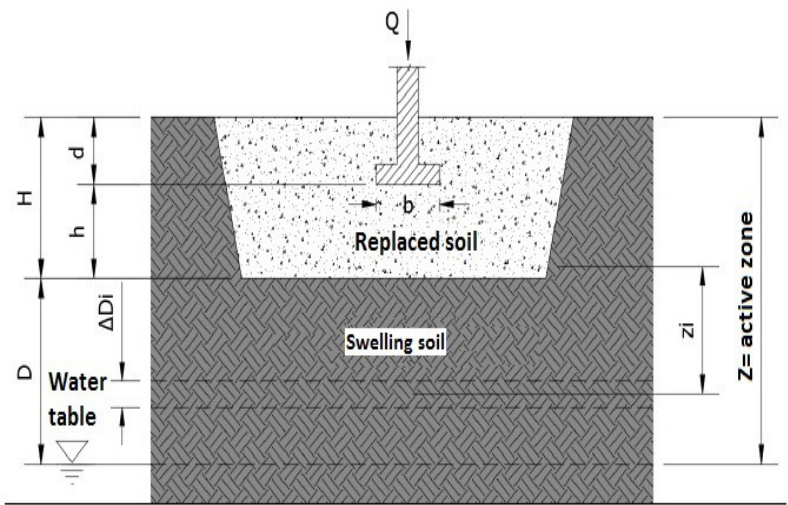

Fig. 8. Variables used for calculation of the depth of soil substitution.

Table 4. Design input parameters. [3]

\begin{tabular}{|c|c|c|c|}
\hline Parameter & Soil 1 & Soil 2 & Soil 3 \\
\hline $\begin{array}{c}\text { Surcharge } \\
\text { load }\end{array}$ & $500 \mathrm{kN}$ & $500 \mathrm{kN}$ & $500 \mathrm{kN}$ \\
\hline Active zone & $5 \mathrm{~m}$ & $5 \mathrm{~m}$ & $5 \mathrm{~m}$ \\
\hline $\begin{array}{c}\text { Depth of } \\
\text { footing }\end{array}$ & $1 \mathrm{~m}$ & $1 \mathrm{~m}$ & $1 \mathrm{~m}$ \\
\hline $\begin{array}{c}\text { Width of } \\
\text { footing }\end{array}$ & $1.5 \mathrm{~m}$ & $1.5 \mathrm{~m}$ & $1.5 \mathrm{~m}$ \\
\hline $\begin{array}{c}\text { Unit weight } \\
\text { of swelling } \\
\text { soil }\end{array}$ & $17.2 \mathrm{kN} / \mathrm{m}^{3}$ & $23.4 \mathrm{kN} / \mathrm{m}^{3}$ & $18.4 \mathrm{kN} / \mathrm{m}^{3}$ \\
\hline $\begin{array}{c}\text { Unit weight } \\
\text { of } \\
\text { substitution } \\
\text { soil }\end{array}$ & $20 \mathrm{kN} / \mathrm{m}^{3}$ & $20 \mathrm{kN} / \mathrm{m}^{3}$ & $20 \mathrm{kN} / \mathrm{m}^{3}$ \\
\hline \multicolumn{2}{|c}{} & & \\
\hline
\end{tabular}

Where $\mathrm{H}$ is the depth of the soil substituted by nonexpansive soil, $d$ is the depth of footing, $b$ is the width of the footing, Q is the surcharge load, and D is the depth of the active zone soil still present after the substitution.

The methodology used to estimate the depth of the over-excavation and substitution is based on calculating an earth-fill weight that equals the swelling pressure for a particular expansive percentage. This expansive percentage is selected depending on the allowable expansion for a particular problem. Equation 2 was used for the estimation of the depth of the earth fill, where $\sigma_{\text {cs }}^{\prime}$ is the swelling pressure determined from the free-swell test for a particular allowable expansive percentage.

$q_{i}{ }^{\prime}=h\left(\gamma_{t}-\gamma_{w}\right)+\mathrm{Q} /\left(\mathrm{b}+\mathrm{h}+\mathrm{z}_{\mathrm{i}}\right)^{2}+\sigma_{\mathrm{cs}}{ }_{\mathrm{c}}$

After calculating the depth of the required substitution, it was estimated that for soil 1 not using the matric suction as part of the considerations to develop the swelling curve under-predicts the depth of the required substitution by $66 \%, 5 \%$ for soil 2 , and $9 \%$ for soil 3.

Thus, using the compression curve instead of the appropriate swelling curve provides results on the nonconservative side.

\section{Conclusions}

Volume changes in swelling soils are directly related to water content variations. These water content variations alter the state of stresses in the soil and produce either contraction or expansion of the soil. Another source of expansion is the trapping of water molecules attract by the clay particle's negative charge. The free-swell test is widely used; however, the swelling percentage obtained from this type of test is in terms of total stresses because the matric suction is not accounted for. Three undisturbed clayey soil samples were obtained from three different locations in the Central Valley of Costa Rica. Sample 1 and sample 3 were collected during the rainy season, and sample 2 during the dry season.

Probably the main disadvantage of the free-swell test is that no measured curve for the swelling stage is estimated for cases where a swelling percentage for a different pressure than the seating load needs to be estimated. It is not possible to have a volume change without having a change in the state of effective stress. Hence, it is imperative that the matric suction of the soil specimen be assessed.

It was hypothesized that the actual swelling curve in terms of effective stresses could have three possible shapes. And, it was observed that the shape of this curve is similar to the one of the Soil-water characteristic curve.

The depths of soil substitution calculated for a shallow foundation using the compression curve and the proposed swelling curve showed that the depth of the required substitution for soil 1,2 , and 3 , under-predicts the depth of the required substitution by $66 \%, 5 \%$, and $9 \%$ respectively when the matric suction is not considered to develop the swelling curve. Thus, using the compression curve instead of the appropriate swelling curve provides results on the non-conservative side. However, further research must be performed to correctly judged the real difference between the two methods.

\section{References}

1. Murthy V.N.S., Advanced Foundation Engineering (CBS Publishers and Distributors, New Delhi, 2007)

2. Mitchell, J.K., Soga K., Fundamentals of soil behavior (John Wiley \& Sons, New York, 2005)

3. Esquivel M. M., Propuesta de modificación del ensayo existente de expansión libre para suelos no saturados(Graduation Project, Costa Rica, 2017)

4. Holtz, R.D., Kovacs, W.D., An introduction to geotechnical engineering (Prentice Hall, New Jersey, 1981)

5. Van Genuchten, M., Leij, F., Yates, S., The RETC Code for quantifying the hydraulic functions of unsaturated soils (EPA, USA, 1991)

6. Baltodano-Goulding R., Tensile strength, shear strength, and effective stress for unsaturated sand (Doctoral Dissertation, University of Missouri, 2006) 